\title{
Boomers, Draggers and Black Boxes: The Operational Legacy of Canada's Oberon Class Submarines, 1983- 1998. ${ }^{1}$
}

\section{Michael Whitby}

Très peu est connu sur les opérations de la force sous-marine canadienne en raison de la nature secrète des opérations sous-marines. Le présent document s'appuie sur des documents opérationnels non disponibles jusqu'alors pour faire valoir que le service, qui n'a été créé qu'en 1961, a atteint sa maturité pendant les années 1980 et 1990, la seconde moitié de la carrière de fonctionnement des trois sous-marins Oberon acquis dans les années 1960. Pendant la première partie de leur carrière ces sous-marins ont été utilisés principalement pour aider à la formation anti-sous-marin de la flotte de surface de la marine nationale. Au début des années 1980, cependant, le personnel expérimenté était en mesure d'amener les Oberon dans de nouveaux rôles à l'appui des alliances militaires du Canada, et de faire valoir les intérêts nationaux. En gardant notre souveraineté, la projection de nos intérêts à l'étranger, et à faire respecter le droit canadien et la protection de nos ressources économiques, les sous-mariniers canadiens ont démontré qu'ils étaient un élément indispensable à l'équilibre de nos forces maritimes.

In terms of public recognition, the Canadian submarine service is among the poor sisters of the international submarine community. The submarine services of other countries, including the United States, the United Kingdom, Germany, Russia, the Netherlands, Italy and Japan, have seen their wartime achievements celebrated in books, television and film. Indeed, well publicized exploits have made national heroes of some

1 This study is largely based upon primary documentation that remains classified, as well as interviews with numerous veteran submariners. The author would like to acknowledge the wise counsel of CDR Bob Bush (ret'd), CDR Mike Craven, RADM Bob Davidson, CDR Bill Irvine, CAPT(N) Norm Jolin, CAPT(N) Keith Nesbit (ret'd), CDR Dave Soule, and especially CMDRE Larry Hickey and $\operatorname{Capt}(\mathrm{N})$ Phil Webster (ret'd). The interpretations remain the author's but it would not have been as well informed if not for the generous and patient assistance of those mentioned above. Dr. Richard Gimblett, Dean Boettger, CAPTs (N) Serge Bertrand and Colin Plows, LCOL Bernd Horn, and Peter Haydon have facilitated the publication process for my research on Canadian submarine operations, enabling the story to be brought to a wider audience.

The Northern Mariner/le marin du nord, XXIII No. 4, (October 2013), 367-398 
submariners. By contrast, the Canadian submarine service, founded only in 1961, has never fired a torpedo in anger. Moreover, when they did meet with operational success towards the end of the Cold War, due to tight security, the details of those missions were known, literally, only to a handful of personnel. With few exceptions, the same applied to missions carried out during the aftermath of the Cold War. That "need to know" silence has shrouded the achievements of the submarine service, and has thus hampered a realistic assessment of their value to Canadian maritime security.

This did not just happen in Canada. In a 1999 review of the book Blind Man's Bluff: The Untold Story of American Submarine Espionage, ${ }^{2}$ which raised the curtain over some aspects of USN submarine operations during the Cold War, American naval analyst Norman Friedman noted "during the Cold War there was widespread belief in the [US] naval community that submariners played little part in peacetime operations, they took few risks, and that they had little tactical competence." Not only did Blind Man's Bluff go a long way in revealing this was "a giant deception," but "the service's misfortune has been general public ignorance of its continuing value at a time of budgetary crisis." ${ }^{3}$ Those very words apply to the Canadian submarine service. As this study of the last fifteen years of the Oberons' service demonstrates, Canadian submarines played a valuable but not largely known or understood role in guarding our sovereignty, projecting our interests overseas, and in upholding Canadian law and protecting our economic resources. In consistently meeting these commitments, Canadian submariners, whose skill and professionalism gained the respect of their allies, demonstrated they were an indispensable element of our balanced maritime forces.

\section{Circumstances Affecting Operations}

Initially, two points require emphasis. First, it must be borne in mind that the modern Canadian Submarine Service was not established until 1961-Canada briefly flirted with submarines during and immediately after the First World War-and that a further seven years passed before all its boats were commissioned. A former United States Navy (USN) fleet boat commissioned as HMCS Grilse in 1961 served as an antisubmarine training platform on the west coast until 1969. She was soon joined by three new-construction Oberon class submarines - known as "O-boats"-acquired from Great Britain: Ojibwa in 1965, Onondaga in 1967, and Okanagan in 1968, all of which were based on Halifax. Rainbow, another ex-USN fleet boat, replaced Grilse on the west coast from 1968-1975. Although a cadre of Canadian personnel had undergone training and experience with the Royal Navy (RN) and USN throughout the 1950s and 1960s - in particular with the RN's 6 $^{\text {th }}$ Submarine Squadron which was based at Halifax from 195567 - and the service benefited from the knowledge of exchange officers from those navies, the submarine service was nonetheless starting more-or-less from scratch. ${ }^{4}$

2 Sherry Sontag and Christopher Drew, Blind Man's Bluff: the Untold Story of American Submarine Espionage (New York: BBS, Public Affairs, 1998).

3 Norman Friedman review, U.S. Naval Institute Proceedings (February 1999), 82-83.

4 For a scholarly account of the Canadian submarine service see Peter Haydon "Canada and 
Support infrastructure, maintenance facilities, training and recruitment programs, and inter-fleet relationships had to be cobbled together. Most importantly, experience had to be gained in what is universally recognized as an extremely complex and challenging form of warfare - the learning curve was probably steepest for the staff that ran the fleet programs, who were almost without exception from the surface community with no experience in mounting submarine operations. Thus, it took a period of time, at least a decade according to some participants, for the service to gain the level of across-theboard experience required to achieve full operational capability. This was a natural development curve that routinely occurs whenever any military introduces a sophisticated new capability, and one that has been echoed with today's Victoria class boats due to the long lapse of time between their commissioning and the end of the O-boat era.

Second, it must be understood that the core of the operational submarine capability, the three Oberons that comprised the First Canadian Submarine Squadron, spent a considerable amount of time, perhaps as much as 20-25 per cent, in the United Kingdom with the RN on what were generically known as "EASTLANT deployments." Since the RN and the Canadian navy both operated a common platform in Oberons and because the Canadian service had not fully developed its training infrastructure, acceptance trials and operational work-ups were conducted in Great Britain under the auspices of the RN. In exchange for these services Canada loaned individual boats to the $\mathrm{RN}$ for short periods, during which time they came under British operational control (OPCON). In addition to acting as training platforms, they were assigned missions as if they were British national assets, and taskings included support to special forces and surveillance missions against Soviet warships. On one occasion, for example, Onondaga gathered intelligence from a new Kara class cruiser transiting the English Channel. Normally, the intent on operations of this type was to get close under the target's keel for an "underwater look"-within about a dozen feet from the periscope-to take photographs, record the acoustic signature and capture electronic emissions. On this occasion the water was too shallow to get underneath for an "underwater look" but Onondaga shadowed the cruiser from about 1000 yards and recorded valuable data. The riskiness of these evolutions was underscored later in the same deployment when Onondaga ran into a sea mount while trying to get underneath a Soviet intelligence vessel (designated "AGI" by western navies) that was popularly known as the "Malin Head AGI" due to the near-permanence of its surveillance position off the north-west coast of Ireland. ${ }^{5}$ With "sharp end" experiences like these and the expanded training opportunities provided by the RN, EASTLANT deployments were extremely popular among Canadian submariners.

the RN Submarine Service: 1915-2000," in Martin Edwards (ed.), 100 Years of the Trade: Royal Navy Submarines, Past, Present and Future (Lancaster: CDISS, 2001), 154-168. For more general histories see, J.D. Perkins, The Canadian Submarine Service in Review (St. Catharines: Vanwell, 2000), and J.H. Ferguson, Through a Canadian Periscope: the Story of the Canadian Submarine Service (Toronto: Dundurn, 1995).

5 Interviews with CAPTs (N) Al Dunlop and Phil Webster and CMDRE Larry Hickey, all of whom served in Onondaga during this deployment. 


\section{Operational Surveillance Patrols}

From the mid-1970s, the Soviets had deployed nuclear-powered ballistic missile submarines (SSBN) into positions from which they could launch a nuclear attack at North American targets. Two or three Project 667A boats- "Yankees" to allied naviesoccupied what NATO navies dubbed the "Yankee patrol Box" east of Bermuda. Departing from their Northern Fleet bases in the Kola inlet, they penetrated the Greenland-Iceland-United Kingdom (GIUK) Gap, and crossed the Atlantic Basin towards Bermuda, which meant they entered or skirted the eastern extremity of the Canadian Atlantic (CANLANT) command zone in deep water off the Grand Banks. ${ }^{6}$ In the 1980s, newer Type 667B "Delta" class SSBNs, essentially enlarged Yankees but quieter and armed with longer-ranged missiles, occupied more distant launch positions in the Labrador Sea. ${ }^{7}$ Countering the Yankee and Delta threat was a critical element of NATO strategy, and starting in 1983, Maritime Command (MARCOM) deployed its Oberon class submarines on dedicated operations known as Operational Surveillance Patrols (OSP) against Soviet "boomers."

This mission marked a significant change. Since their acquisition in the 1960s, the O-boats had been employed almost exclusively as "clock work mice," providing target services for the anti-submarine assets of Canada and its NATO allies. All NATO navies allocated submarine time for anti-submarine warfare (ASW) training, but in the Canadian context, the emphasis on training combined with the small number of boats on strength meant the Oberons had limited opportunity to prepare for their assigned wartime role under NATO, which was to form part of the ASW barrier in choke points like the GIUK Gap and the Davis Strait. Submarine-versus-submarine operations are an exceedingly complex form of naval warfare, which require comprehensive training to first attain, and then maintain, proficiency. In the case of the Canadians, however, preparation was limited to sporadic submarine-versus-submarine training serials (SSXs) that were typically of short duration, and large set piece NATO exercises. Moreover, apart from the EASTLANT deployments mentioned above, the O-boats' operational experience was limited to rare surveillance missions against Soviet surface assets, usually intelligence vessels (AGIs), working in the NATO CANLANT zone. Thus, when the opportunity arose to conduct sustained operational missions in home waters - Canadian missions under Canadian operational control - it provided a real boost to the submarine community.

The decision to embark upon OSPs derived from a confluence of factors. First, the Oberons were emerging from the Submarine Operational Update Program (SOUP), which, according to one commentator, upgraded the boats from "a semi-passive ASW

6 Larry Robideau, "Third Battle of the North Atlantic, 1962-1991," Cold War Times, February 2006.

7 Norman Polmar and K.J. Moore's Cold War Submarines is the best source for Soviet submarine design, while Owen R. Cote's, The Third Battle: Innovation in the US Navy's Silent Cold War Struggle with Soviet Submarines (Newport: Naval War College Press, 2003) is the most comprehensive study of Cold War ASW. 
training vessel, to a fully capable offensive undersea weapon platform." ${ }^{8}$ Among other improvements, SOUP enhanced surveillance capability through the fitting of better passive sonar processors and a digitalized fire control system. ${ }^{9}$ These upgrades enabled attack teams to conduct Target Motion Analysis (TMA) on up to four targets simultaneously. As commentators have explained "using automatic TMA on multiple targets, a submarine commander could form a picture of the underwater and surface activity around the submarine, a sort of equivalent of a radar picture, without giving the submarine's position away by pinging with sonar."10 In addition, digital processing helped to classify the increased number of contacts detected by the improved sonar systems. In combination with the Oberons' legendary quietness and long endurance, SOUP transformed the boats into potent ASW platforms.

Despite these upgrades, one system that needed improvement was narrowband sonar. When Okanagan conducted the first OSP in 1983 she received a FAS 1B narrowband frequency analyzer as a special mission fit. Passive sonar had become the predominant ASW detection system, particularly in the context of submarines hunting other submarines. O-boats had both active and passive sets, but since active transmission ("pinging") could reveal their presence, Canadian submariners took it as a matter of pride to avoid the use of this equipment on operations. Put in the simplest terms, whereas active sonar produces an echo when the transmitted pulse bounces off a target, passive sonar detects sound emitting from the target itself. This falls into two categories: broadband, which typically includes sound such as flow water moving over the hull and propeller cavitation; and narrowband, which typically includes low-frequency noise generated from machinery such as pumps and generators. ${ }^{11}$ As ASW analyst Tom Stefanick explained, "Submarines make different kinds and levels of sound at different speeds. When a nuclear-powered submarine is stopped, it must continue to run reactor cooling pumps, generators and air conditioning. Those generate narrowband spectra that are relatively independent of speed." Besides picking out a submarine amongst a myriad of ocean noise, narrowband also enabled a remarkable degree of classification. "Passive sonar operators," Stefanick continued, "can sometimes identify the nationality and class of an unknown submarine. Unique machinery noises may even permit identification of a particular submarine." ${ }^{12}$ Accordingly, NATO ASW forces not only tracked Soviet SSBNs to determine their location and patrol patterns, but also to record their acoustic signatures,

8 Thomas Lynch, "Modernizing the Subs: SOUP," in Canada's Navy (Calgary: Corvus, 1985), 168-170.

9 There is a general assumption that the Oberons received Mark 48 torpedoes as part of SOUP, however, although acquisition of the torpedoes was approved under the program, they were not fitted until the late 1980s.

10 Robert Gardner and Norman Friedman (eds.), Navies in the Nuclear Age: Warships Since 1945 (London: Conway, 1993), 71.

11 Cote, The Third Battle, 22-24. USN, "Introduction to Naval Weapons Engineering: Introduction to Sonar Systems," http://www.fas.org/man/dod-101/navy/docs/es310/ uw_acous/uw_acous.htm accessed 1 June 2010.

12 Tom Stefanick, Strategic Antisubmarine Warfare and Naval Strategy (Lexington: Center for Defense and Disarmament Studies, 1987), 8-9. 
which enabled analysts to trace the activity of individual boats. FAS 1B introduced Canadian submariners to this capability but due to the fact they only had a small number of sets, perhaps one or two, they did not receive enough training and experience to get the most out of the system. Thus, according to a 1986 analysis, FAS 1B "was not generally understood," and there was "general weakness in narrowband theory knowledge in Canadian submarines."13

A weakness of all conventional submarines is that their relatively low submerged speed - up to about 17 knots for an Oberon depending upon conditions-inhibits their ability to search large areas of ocean. Oberons, moreover, could not cover distance quickly and still remain covert; with speed came noise, with noise came counterdetection. Adding to the problem was their need to snort regularly, about every four-six hours depending on the amount of battery power being consumed, which impaired search capability and sonar performance. However, the Oberons gained reach through cooperation with the Lockheed CP-140 Aurora, which entered service in the early 1980s. Probably the most effective maritime patrol aircraft (MPA) of their generation, Auroras married the airframe of the USN's P-3 Orion with the avionics package of the new S-3 Viking carrier-borne ASW aircraft. With relatively high speed, extensive sensor and weapons suites, and a crew that included four tactical navigators and three sensor operators, Auroras proved capable of tracking Soviet submarines for extended periods. Shortly after the CP-140s began flying operations, the MARCOM commander, ViceAdmiral J.A. Fulton, informed Admiral H.D. Train, USN, Supreme Allied Commander Atlantic, that a team of Auroras had tracked two Soviet SSBNs continuously over three days; after accepting congratulations, he told Train they had also tracked the USN attack submarines trailing them. American SSNs were supposed to be too quiet for that, and, according to Fulton, the look in Train's eyes was one of surprise and consternation. ${ }^{14}$

Canadian submariners had long enjoyed a close relationship with the MPA community, and it is not surprising that the senior staff officer (sea operations) on Fulton's staff, Commander Keith Nesbit, grasped the potential of a partnership between the upgraded Oberons and the new Auroras. Nesbit was a highly respected submariner, perhaps the most respected in our history, known for his intellect, vision and leadership; he had worked as a professional pianist before joining the navy, a career he continues today. When commanding officer (CO) of Okanagan in the mid-1970s he and his officers had devised the infamous "Dolphin Code," an informal cipher submariners used to communicate with - really tweak - adversaries during exercises, particularly "skimmers," as they called their surface ship brethren. ${ }^{15}$

13 DCOS Ops, "Patrol Instructions - Operational Surveillance Patrol 1/83", 29 June 1983; and CO Okanagan, "Operational Surveillance Patrol 1/83, 30 Jun 83-19 Jul 83 Patrol Report," 19 June 1983.

14 Whitby, Gimblett and Haydon, The Admirals, 328; Fulton to author.

15 For example, Dolphin 58 translates to, "With sub-killers like you around, I look forward to a long life." The Dolphin Code is still used by submariners of several navies, including the RAN and RN. A complete list can be found at http://www.chebucto.ns.ca/ ac121/soca/ code.htm. 
Nesbit had long been critical of the tendency of senior officers to view Oberons strictly as training platforms, overlooking their operational capability. He also thought it vital to demonstrate to the USN that Canada could look after its own area of responsibility. To Nesbit, deploying O-boats on operational patrols was like "putting a chunk of Canada out on station." 16

There was a final, practical reason for deploying Canada's submarines against Soviet SSBNs. Although Auroras could track them there was concern whether their "lightweight" Mk 46 torpedoes, the same type used by Canadian destroyers and Sea King helicopters, could actually destroy Soviet nuclear submarines, the latest of which had durable, double-hulls. The Oberons' "heavyweight" Mk 37 torpedoes packed far more punch, and, even though they had a well-earned reputation as a temperamental weapon, their warhead was thought powerful enough to destroy a boomer. ${ }^{17}$ Given the destruction that SSBNs could wreak, "killing" had to be the objective. The challenge was to get the Oberons into position to achieve a fire solution. Commander R.E. Bush, a respected submariner and veteran of a number of OSPs, believes that Fulton and Nesbit wanted to prove to the Americans that they could get an O-boat into position to kill a SSBN. The little chunk of Canada out on station in the North Atlantic had to have teeth.

Mounting OSPs was a distinct challenge for Maritime Command. In one of his initial planning memos, Nesbit conceded 'because of our boats' somewhat limited experience in this regard (most of which has been obtained from tasking when under British OPCON [operational control]) and because of MARCOMHQ's lack of practice at directing/controlling submarines in a fully 'operational' sense, there should be a lot to learn." ${ }^{18}$ Under NATO protocol, before each patrol MARCOM had to earmark a submarine patrol area (SPA) through the Commander Submarines Atlantic (COMSUBLANT) at Norfolk, who oversaw NATO submarine operations in the Atlantic. ${ }^{19}$ This "Notice of Intent" reserved an operational area for the boat, including a "moving haven" for the transit, which was intended to reduce the risk of mutual interference and collision with other NATO submarines. ${ }^{20}$ Once the patrol was launched,

16 Nesbit draft ms, "SMIDS: Submarine ideas...for a 'rationale' paper," in author's possession.

17 The Mk 37 torpedoes used by the O-boats had a $330 \mathrm{lb}(145 \mathrm{~kg})$ warhead whereas the Mk 46's was $98 \mathrm{lb}(44 \mathrm{~kg})$. In the late 1980s, the O-boats were armed with the even more powerful Mk 48 torpedoes.

18 CDR K. Nesbit, “Canadian 'O' Class Submarines - Operational Patrols,” 13 October 1982.

19 To ensure effective liaison, since the 1970s a command qualified Canadian submariner has served on COMSUBLANT staff.

20 Notices of Intent not only involved demarking the actual patrol area but also setting a "moving haven" that covered the speed of advance for the transit to and from the patrol area, thus submarine operations were tightly scripted. Water Space management is an important aspect of submarine capability, helping to avoid "Blue-on-Blue" encounters. Moreover, since the NATO navies operating submarines inform each other of their demands for water space, they have an idea of overall submarine activity. Notices of intent were also used to send a "message" about submarine activities. If a navy does not have a submarine capability it does have the ability to manage and maintain an awareness of submarine activity. For more see Capt (N) Phil Webster, "Arctic Sovereignty, Submarine Operations and Water Space 
a small sealed cell of experienced submariners was established at the Maritime Operations Centre (MOC) in Halifax to co-ordinate each mission. Their job as controllers was to sift intelligence of SSBN movements from SOSUS, MPAs and other sources, and vector the O-boat on patrol into the best position for an interception. Communications procedures also had to be confirmed with the signal establishment at Mill Cove, Nova Scotia. Security surrounding all these preparations was tight, and aside from the controllers and the command team of the submarine, only a handful of senior officers were aware of individual operations. In some instances, submarine commanding officers did not even inform their entire crew of the mission.

Under patrol instructions, O-boats were expected to remain covert throughout the entire mission. This was a challenge since the Soviets habitually positioned their own surveillance assets in the Northwest Atlantic. "Research" vessels and weather ships could usually be found in the CANLANT zone, and Soviet military aircraft routinely probed our air defence systems. Although not normally equipped with sensors beyond standard commercial radar, the ubiquitous Soviet fishing fleet also had to be avoided. There was also concern that the Soviets used satellites to detect submarine movements, either visually or through thermal or wake detection technology; therefore, patrol orders included reference to expected exposure to satellites. Most germane, however, was the threat of counter-detection by the very targets they were pursuing, Soviet SSBNs. Here, Oberons were thought to be on fairly safe ground. They were exceedingly quiet; in fact Auroras had trouble tracking them even when they knew their general location. Moreover, Soviet passive sonar systems were appraised as sub-standard, and since their boats were also noisier it was thought they would have difficulty hearing an O-boat over their own self-generated noise. ${ }^{21}$ Because of these shortcomings Soviet COs relied more on active sonar, "pinging" as often as every three hours, but this usually disclosed their location. ${ }^{22}$ Given all these factors, if a Canadian O-boat maintained effective quiet routine, the risk of counter-detection was considered to be low. It will not be until access is gained to Soviet naval records, if indeed even then, that we will know if this assessment was accurate.

In all, Canadian submarines mounted eight Operational Surveillance Patrols between 1983 and 1987..$^{23}$ Except for one patrol to Hudson's Strait, the missions focussed on the Labrador Sea or the eastern extremity of the CANLANT area of responsibility off the Grand Banks. Some boats came up empty on their patrols, unable to find their Soviet counterparts because of the challenging water conditions that prevail off

Management," Canadian Naval Review vol 3, no. 3 (Fall 2007), 14-16.

21 See Norman Friedman, Seapower and Space: From the Dawn of the Missile Age to NetCentric Warfare (London: Chatham, 2000), 200-208; Cote, The Third Battle, 61; and Polmar and Moore, Cold War Submarines, 185-187.

22 Polmar and Moore, Cold War Submarines, 173 n 32.

23 “OSP 1/83"- Okanagan (June-July 1983); "OSP 2/83' - Ojibwa (Nov-Dec 83); "OSP 1/85"Ojibwa (Feb-March 1985); "OSP 2/85"- Onondaga (Oct-Nov 1985); "OSP 1/86"- Ojibwa (June-July 1986); “OSP 2/86”- Onondaga (Nov-Dec 1986); "CANLANT OPS”- Onondaga (July 1987); and "CANLANT PATROL”- Okanagan (Sep-Oct 1987). 
the east coast or simply because there was no activity in the Submarine Patrol Area (SPA) at that time. But even if they did not achieve contact with SSBNs, they met secondary objectives to conduct basic intelligence gathering (BINT) on other Soviet assets. In short, the Oberons almost always returned with something, but, most importantly, the patrols provided crucial operational experience at both the submarine and command and control levels. The complete OSP program has been described elsewhere and for this study two patrols can stand for the rest, indicating the character and challenges of the operations. ${ }^{24}$

In November 1983, Lieutenant-Commander N.P Nicolson took Ojibwa to the eastern edge of the CANLANT zone for OSP $2 / 83$, the second such operation. ${ }^{25}$ Nicholson was a respected submariner, in fact one of his officers later concluded that if had to go to war under any captain, he would be his choice. On this mission Nicholson was not only tasked to attempt to intercept a Yankee SSBN but also to gather electronic intelligence (ELINT) on Soviet TU-95 "Bear" reconnaissance aircraft that regularly overflew the CANLANT zone, monitor the activity of surface vessels, and observe the change-over of two Soviet weather ships that occupied a semi-permanent station in the North Atlantic. In addition Ojibwa was to conduct a tracking exercise with the Los Angeles class SSN USS Atlanta (SSN 712) as it transited the CANLANT zone. This wide range of objectives against air, surface and sub-surface targets underscores the impressive surveillance capability of a modern submarine.

Ojibwa departed Halifax on 14 November 1983, feinting to the southwest before settling on an easterly course. ${ }^{26}$ While passing south of Sable Island she monitored electronic emissions from the Soviet research vessel Academik Korolev, satisfying one of her secondary objectives. On 17 November Ojibwa detected a pair of TU-95 Bears that were presumably testing the North American air defence system while en route to Cuba. The large ungainly aircraft flew within 5-10 nautical miles of Ojibwa, forcing Nicolson to break off snorting to reduce the risk of counter-detection. ELINT indicated that the Bears operated their search radar intermittently for 2-4 minutes every 15-20 minutes. Although "BINTing" Soviet air and surface activity was important, the main objective of OSPs was

24 For the history of the entire OSP program see Michael Whitby, “'Doin' the Biz': Canadian Submarine Patrol Operations Against Soviet SSBNs, 1983-87," in Bernd Horn (ed.), Fortune Favours the Brave: Tales of Courage and Tenacity in Canadian Military History (Toronto: Dundurn, 2009).

25 O-boat COs were relatively junior officers, in most cases only recently promoted lieutenantcommanders. They were also usually quite young; Larry Hickey was just 29 when he took over Onondaga. Those characteristics, in combination with the boost from having passed the infamous Perisher command course, meant they oozed confidence. It would be inaccurate to describe them as cocky or arrogant, although some undoubtedly were, but they were universally bold and aggressive. They never pushed their commands past the point of safety, yet they knew how to get the most out of their boats and sailors. "Daring" is not a word normally associated with a category of naval type command - Motor Torpedo Boats might be the only other instance - but with O-boat COs it applied as a matter of course.

26 With the exception of Onondaga's OSP in November 1986 when she transited to her SPA via the Gulf of St. Lawrence and the Strait of Belle, all other boats headed northeast from Halifax. 
to monitor submarine activity, and shortly after arriving in her patrol area Ojibwa experienced two encounters that validated her mission but also demonstrated the challenges of undersea warfare.

At $0100 \mathrm{z} 18$ November, while Ojibwa came around to a course of $047^{\circ}$ below the layer in deep water east of the Tail of the Bank, her Type 2007 passive sonar gained a fleeting contact at about 7000 yards range. The sonar team double-checked the contact with the Type $187 \mathrm{c}$ attack sonar, which detected what seemed to be the sound of turbine whine down the same bearing. After tracking for 15 minutes Nicolson assessed the contact as a possible submarine, which TMA indicated was steering $250^{\circ}$ at about eight knots. Ojibwa's closest point of approach (CPA) was about 4000 yards. At $0148 \mathrm{z}$ the contact initiated the tell-tale tactic of clearing its baffles - circling back to ensure it was not being shadowed by another submarine lurking behind its propeller cavitationaltering to $120^{\circ}$ for five minutes before resuming its original course. Ojibwa lost contact at $0158 \mathrm{z}$ and Nicolson elected not to pursue for fear the speed required might reveal his presence. Following procedure Nicolson immediately attempted to report the contact to MARCOM but the gremlins that consistently disrupted ship/shore communications in this part of the Atlantic intervened. Ojibwa was forced to remain at periscope depth for more than eight hours trying to raise MARCOM and an exasperated Nicolson complained "all conceivable HF frequencies and shore stations have been tried... there is no chance Ojibwa has not been DF'ed," that is, located by Soviet radio stations.

After the patrol Nicolson claimed a definite submarine contact based on the following criteria:

a) A quiet bearing rate;

b) A short detection range (approximately 7000 yards);

c) Biological noise on the contact bearing (common around submarines);

d) Course alterations;

e) No visual contacts in conditions of good visibility;

f) Intermittent $187 \mathrm{c} \mathrm{high}$ channel contact; and

g) Whine audible on the stern aspect.

COMSUBLANT, the repository for intelligence of submarine movements, later advised MARCOM it had no candidates for the contact, "friendly or otherwise." But Nicolson was undeterred and remained convinced the contact was a nuclear submarine, and suggested it may have been a Soviet Project 671 Victor attack boat transiting to Cuba to replace another Victor undergoing repair. ${ }^{27}$ Others speculate it may have been an allied boat.

Two days after the incident, Ojibwa encountered the bulk carrier Columbia Liberty east of the Flemish Cap. With no other contacts evident, Nicolson decided to test

27 In a fascinating incident, on 31 October 1983 a Victor III was found wallowing immobile on the surface 470 miles east of Charleston, SC. US forces then tracked it as it was towed to Cienfuegos, Cuba to repair a damaged propeller. Apparently it had got caught up on the towed array of the frigate USS McCloy, which had been tracking the SSN. Polmar and Moore, Cold War Submarines, 160. 
his attack team by carrying out a simulated torpedo attack on the unsuspecting ship. However, as the boat approached the attack team detected anomalies between bearings reported acoustically from those viewed through the periscope. Sonar operators "initially considered that [Type] 2007 was cutting a strong side lobe, however, when Ojibwa altered to port at CPA, the 2007 'side lobe' broke fast right at a higher bearing rate (about 20-25 deg/min) than the Columbia Liberty." Analysis revealed two contacts: one the Columbia Liberty, the second at about half the range of the merchant ship and emitting sounds associated with military machinery. Nicolson concluded "it was very likely a submarine travelling on the MV's starboard quarter at close range in order to obtain an acoustic cover." These were known Soviet tactics, especially in areas like the Northwest Atlantic where there was a high probability of detection by SOSUS. ${ }^{28}$ Unfortunately, contact was lost before this could be confirmed. However, four days earlier, Ojibwa had received intelligence that a Yankee class SSBN was on passage to its patrol box off Bermuda. Using "furthest on circles and great circle track to the Soviet SSBN patrol station," Nicolson concluded, "that the contact was YL-181." This estimate seemed accurate, and COMSUBLANT later confirmed it was "not US or known friendly submarine."

It is impossible to verify either of the submarine contacts claimed by Ojibwa. This was a recurrent problem of Cold War ASW, since there was no "flaming datum" (an attack on friendly shipping that left no doubt about the presence of a submarine) nor usually even sighting reports to confirm "enemy" activity. It was an acoustic war, and submariners and analysts often disagreed on the authenticity of contacts. This is not a new phenomenon. During the Second World War, the RN's U-boat Assessment Committee often cast doubt on claims of sunken U-boats. It was only after historians were able to compare Allied and German records that issues were resolved, and still the evidence was too incomplete or contradictory in some cases to come to any firm conclusion. The problem with Cold War ASW research is that there is no access to the submarine patrol records of our allies, let alone the Soviets. In the case of OSP 2/83, the situation was further obscured by glitches in the recording process onboard Ojibwa, which prevented sufficient data being gathered for analysis. As a result the validity of Ojibwa's contacts remain a mystery. Nonetheless, crew members remain convinced that both were submarines.

After the cancellation of the scheduled tracking exercise with USS Atlanta, which was perhaps diverted to investigate YL-181, Ojibwa spent the last part of her patrol monitoring the changeover of the Soviet weather research vessels Musson and Passat (AGOR) at Ocean Station Charlie, some 850 miles northeast of St. John's, Newfoundland. This should have been a routine surveillance evolution. Working from intelligence provided by CP-140s, at 2220Z 29 November Ojibwa found the AGOR Musson sitting motionless, presumably conducting weather research. Ojibwa moved in submerged to about 1000 yards but could not get closer due to a high sea state, which exposed the periscope to detection. Nicolson opened range to about 12,500 yards to await the second AGOR, but at $0725 \mathrm{Z} 30$ November heavy smoke suddenly choked the engine

Polmar and Moore, Cold War Submarines, 174. 
room, and Ojibwa suffered a complete loss of propulsion.

As a post-mission analysis described with considerable understatement, this left the boat in an "unpleasant ship control situation." The boat was submerged, apparently with a fire onboard, close to Soviet units. These are precisely the situations crews train for, and Ojibwa's re-acted with speed and professionalism. While sailors sought the cause of the smoke, Nicolson surfaced and tried to remain covert. ESM confirmed that Musson's radar was emitting, but Nicolson used auxiliary power to keep stern-on to the AGOR, reducing Ojibwa's radar profile. In the meantime, engineers found the cause of the propulsion failure, and by $0917 \mathrm{Z}$ had jury-rigged repairs so that the boat could get under way on the port main motor. However, Ojibwa was still not out of the woods. Within an hour the "unpleasantness" continued when ESM picked up another Soviet radar to the southeast, which was soon classified as the Passat. As Nicolson described in his patrol report, "at $1100 \mathrm{Z}$ Passat was sighted briefly at $12 \mathrm{Kyd}$. Ojibwa maintained a stern aspect to this closer AGOR and Passat continued North to RV with Musson. It is considered likely that both Musson and Passat detected Ojibwa on radar but because of the range, stern aspect, lack of lights, high sea state and poor visibility (frequent rain and hail showers) did not classify Ojibwa as a submarine." Nicolson's hunch was probably correct since the AGORs would have relished the opportunity to inspect a surfaced submarine but made no move to close. Having probably saved the day through his manoeuvring under emergency conditions, Nicolson withdrew and once well clear of the area stopped to effect repairs. ${ }^{29}$ Engineers soon had both main motors back on line, and the submarine began her submerged transit to Argentia. She carried out one last surveillance task on her way home when she responded to a flash tasking to take ESM readings on a pair of Bear aircraft sniffing around the CANLANT zone just east of St. John's.

There was no doubting the value of OSP 2/83. Ojibwa had conducted surveillance on Bear MPAs, a possible SSBN, an unidentified SSN, and two AGORs. Yet, the on-board fire was not the only set-back. Unhappily, although the boat had gathered a great deal of useful intelligence, most of the taped sonar data could not be analysed due to equipment or procedural problems. Despite that, analysts were impressed by Ojibwa's record keeping and recommended the data form the basis of a more rigorous operational analysis regime for similar patrols. ${ }^{30}$ Ship-to-shore communication between Ojibwa and Halifax had also been problematic and analysts recommended the boats be fitted with satellite communications systems (SATCOM) to ensure reliable and secure communications; that would not come until the 1990s. Finally, although Ojibwa had encountered two submarines, she had been unable to trail them. Both Nicolson and the subsequent analysis by the Maritime Warfare School emphasised that boats needed to be permanently fitted with narrowband equipment such as FAS 1B as well as a towed array.

29 An Aurora over flew the rendezvous but noticed no unusual activity. The MPA also spotted Ojibwa on the surface, but in keeping with instructions made no attempt to contact the boat.

30 See for example, CO CFMWC, "Operational Analysis - Operational Surveillance Patrols," 3 April 1984. The CO CFMWC recommended an analysis regime similar to that used for certain MPA missions. 
Unfortunately for Canada's submariners, MARCOM put priority on fitting its newly developed towed array system in surface ships instead of submarines - the only NATO navy to follow that practice - and the Oberons would not have the benefit of "tails" until late in their service. OSP 2/83 had proved that O-boats could detect submarines but without sophisticated detection and analysis systems, they were unable to standoff at $7000-10,000$ yards like a USN SSN with a towed array. Instead, they had to snuggle up to close, white-knuckle range of contacts, increasing the risk of collision and counterdetection. When they formulated the plan for OSPs, Nesbitt and his superiors at MARCOM HQ had envisioned that "each operationally available boat [would] conduct at least one such patrol annually." That seemed a reasonable commitment, and would result in no fewer than two or three patrols a year, with all the accrued benefits. Unfortunately, the training priority accorded the Canadian submarine fleet intervened, and thirteen months passed before another OSP could be mounted. Nonetheless, in the interregnum between OSPs $2 / 83$ and $1 / 85$ the submarine community attempted to fine-tune the operations. As a result, the operation Ojibwa embarked upon in late February 1985, turned out to be the most successful—it was also certainly the most dramatic — patrol of its kind.

On the afternoon of 25 February 1985, Ojibwa departed Halifax for a patrol area in the Labrador Sea southwest of Greenland where Soviet Delta SSBNs regularly occupied their missile firing positions. Her $\mathrm{CO}$ was now Lieutenant-Command E.P. Webster, a youthful looking officer known as "Ace" to his colleagues. After a nine day transit in poor weather Ojibwa reached her patrol area on 6 March 1985. Aside from a number of inconclusive long-range sonar hits there were no other signs of submarine activity, and Webster worried the patrol might come up empty. The picture improved on 10 March when they received intelligence that a Soviet SSBN, designated LD-010, had been detected moving into the CANLANT zone. As Ojibwa awaited cueing, CP-140 Auroras, guided by information from SOSUS, flew constantly, sewing sonobuoy patterns in an attempt to find the boomer. In waters notoriously bad for sonar and with the SSBN likely running deep and slow to reduce its signature, this was an exceedingly difficult task; as one submariner recalled, "it was a very hard place to find a quiet submarine." 31 Finally, after four days searching MPAs localized the contact, classified it as a Delta class SSBN, and controllers sent Ojibwa north to intercept.

Since the 1970s American attack boats had attempted to shadow every Soviet SSBN throughout its patrol. The rationale was brutally straightforward. In 1985 US Secretary of the Navy John Lehman announced that American SSNs intended to attack Soviet missile boats "in the first five minutes of the war." 32 Although this was the first public declaration of the strategy, the Soviets had been aware of it for some time-

31 CDR R. Bush to author, 25 October 2007.

32 Cited in Polmar and Moore, Cold War Submarines, 173. 
probably from information provided by the infamous Walker spy ring. ${ }^{33}$ In an attempt to preserve their first strike capability, they sometimes used their own attack boats to escort their SSBNs. This practice, apparently used by both sides during the Cold War, was known as "delousing," and in the early 1980s the Soviets introduced the new Project 671RTM Victor III class SSN into this role. Victor IIIs were the most advanced submarine yet produced by the Soviets and they quickly acquired almost mythical status within the NATO ASW community. Although they could be tracked with great difficulty through the GIUK Gap and other choke points, once they made the open Atlantic they were extremely elusive.

On 16 March, while Ojibwa searched for the Delta, controllers informed Webster that a Victor III was in the immediate area. Webster quickly took his boat deep into the sound convergence layers where sonar achieved best results and soon picked-up a contact. Although initially classified as biological, further investigation indicated it might be a submarine, and this was eventually substantiated by an active sonar transmission from down the same bearing. Since Soviet submariners routinely utilized their active sonar, this was probably confirmation of their presence. It also signified that Ojibwa may have been counter-detected. The next time Webster went to periscope depth to check communications, he received a report that suggested Ojibwa had passed close to the Delta and probably the Victor as well. At the same time, controllers ordered Webster south along the projected course of the SSBN.

The next 72 hours brimmed with tension. As Ojibwa moved south, Auroras sustained a maximum effort, flying around the clock to track the Delta. With SOSUS support they again managed to localize the contact, and on the afternoon of 17 March, Webster received co-ordinates that enabled Ojibwa to close the Delta. It was still a long, challenging search. Biological contacts fouled sonar and the SSBN used the standard Soviet tactic of keeping close to the North Atlantic Ridge to mask its signature. Teamwork between the submarine and MPAs remained almost seamless. When Ojibwa had to snort MPAs then cued her back to a promising area. Finally, Ojibwa found the target. At $0102 \mathrm{Z}$ on $19 \mathrm{March}$, the day before she was scheduled to begin her return passage to Halifax, the sonar team gained hits with both 2007 and 187. A firing solution was immediately input into the fire control system, and Target Motion Analysis tracked the Delta as it circled to clear its stern arc. The big missile boat kept coming and passed so close down the starboard side-Webster estimated under 800 yards - some of the crew claimed they could hear the quiet thumping of machinery as the SSBN slunk by. Webster recalls no real excitement in the boat; the crew just went about their business, quietly and professionally. Ojibwa stuck with the Delta throughout the $20^{\text {th }}$, tailing her from about 2000 yards. Each time they snorted Auroras guided them back into contact. All the while Ojibwa gathered a treasure trove of acoustic intelligence.

33 Over a twenty-year period, Warrant Officer John Walker, USN and three others provided the Soviets with intelligence on USN submarine operations, including ciphers and signal traffic. This material would have provided unique insight into USN submarine activity, and perhaps of its allies. See John Barron, Breaking the Ring: The Bizarre Case of the Family Spy Ring (New York: Houghton, Mifflin, 1987); Polmar and Moore, Cold War Submarines, 285. 
After hours of what now seemed like routine shadowing, the situation suddenly deteriorated. When the Delta turned to clear its baffles in the late hours of 20 March, a second contact popped up on Ojibwa's sonar, heading the other direction, which Webster concluded was the Victor III he had been warned about four days earlier. The "delouser" did its job. Turning towards the Canadian boat it lit up Ojibwa with active sonar. The effect was dramatic. Soviet SSNs used high frequency active sonar that NATO codenamed "Blocks of Wood"; the sound it made on the hull of its target was precisely that of a pair of two-by-fours being slapped crisply together. ${ }^{34}$ Certain he had been detected, Webster now faced a difficult situation. His primary responsibility was the safety of his boat and he was far from home, so far that if something went wrong his nearest refuge was the UK not Halifax. Moreover, he was manoeuvring in close proximity to two adversaries, one of which was trying to drive him off. Rumours of collisions between NATO and Soviet submarines abounded, and current unofficial estimates put the number at as many as forty incidents, ${ }^{35}$ Webster did not want to join that company. Due to begin his homeward passage within hours, and already possessing acoustic data from both contacts, at 230020 March Webster broke off contact. Summarizing the drama in his patrol report, he ruefully noted, "was counter-detected... and actively prosecuted....The second submarine was successful in riding off the patrolling unit."

Ojibwa had conducted the most successful surveillance patrol mounted by an Oboat in Canadian waters. It certainly achieved Commander Nesbit's objective to demonstrate to the Americans that we could look after our own backyard. During the return passage to Halifax, COMSUBLANT notified MARCOM and Ojibwa, "Your recent ASW prosecutions most impressive and productive. Your efforts have contributed significantly to the LANTFLT ASW picture and have not gone unnoticed." 36 That was about as wide as the celebration got since until recently OSP 1/85 remained cloaked in secrecy. When Ojibwa reached Halifax, the squadron commander mustered the crewWebster had kept them all apprised of the situation - and threatened if anybody uttered a word about the patrol he would cut off a vital part of their anatomy. Likewise, when the Commander MARCOM reviewed the patrol with Nesbit and Webster, he concluded they had better keep the information to themselves.

Post-operation analysis found praise for the MPA/submarine "co-op", as well as familiar discussion of communications short falls, the failure to forward up-to-date intelligence information, and the fact that O-boats urgently needed SATNAV and a towed array. There was also disagreement about the identity of the second contact detected on 20 March. Some analysts thought it might have been an American SSN that was trailing the Delta, and wanted to ward off Ojibwa. That may have been the case, but it was probably not in line with the tactics used by American boats. By this time virtually all American SSNs were fitted with towed arrays, which enabled them to standoff at much

34 The formal name for the sonar was the MGK-100 Kerch. Polmar and Moore, Cold War Submarines, 173.

35 Polmar and Moore, Cold War Submarines, 174.

36 CFT 24 to CTF 302, 155026 March 1985. 
further ranges from contacts. There was thus no reason for them to get in as close as Ojibwa and the other boat. Moreover, with intelligence indicating that a Victor III was in the area, it is likely that Webster's appreciation was correct. If that was the case, and if the Victor had in fact detected Ojibwa, and perhaps classified her as an O-boat, then the patrol demonstrated to the Soviets as well as to our allies that Canada was indeed capable of monitoring submarine activity in our waters.

In 1987 Soviet submarine activity in the Northwest Atlantic virtually ceased when incoming Premier Mikhail Gorbachev scaled back naval operations, including the forward deployment of SSBNs off North America. This ended OSPs (although O-boats continued surveillance of Russian surface ship activity, which continued after the end of the Cold War). During their eight missions O-boats trailed about a half dozen Soviet nuclear boats for less than a week in total, and in only one instance did they stalk their adversary for more than a few minutes. In contrast, in 1978 the American nuclear attack boat USS Batfish (SSN 681) shadowed a Yankee for 50 days, sticking with the boomer throughout virtually its entire patrol. Since information about other Cold War surveillance missions conducted by USN SSNs remains sealed - as well as those by the RNBatfish's feat stands as the "gold standard" for submarine ASW. ${ }^{37}$ The variance between the USN and Canadian efforts seems staggering, but one must be careful with the comparison. Notwithstanding the enormous advantage in endurance and mobility held by a nuclear-powered submarine like Batfish, the USN had decades of experience in submarine operations, involving hundreds of boats and thousands of sailors. In contrast, OSPs represented MARCOM's first foray into sustained, dedicated submarine operations. That Oberons appear to have intercepted adversaries on four of the eight missions, and that the command and control organization grew increasingly effective, indicates a level of success that was both tangible and laudatory.

What did the OSP experience mean to the Canadian submarine service and say about its capability? More than anything, the missions finally gave submariners the opportunity to train properly for their prospective wartime role. Moreover, with much of the surface navy battling the effects of "rust-out," the O-boats, along with a few towed array-equipped destroyers, were one of the few naval platforms fulfilling a significant operational role. That was not lost on submariners, but apart from engendering pride, participation in the missions sharpened their skill. One submarine captain, L.M. Hickey, recalls "the OSP experience (in command or in a senior appointment aboard a boat on an OSP), made us better COs. They contributed to the development of boldness, aggressiveness, 'stick-to-it-iveness,' and a better appreciation of how to drive submarines

37 See Thomas B. Allen, "Run Silent, Run Deep," Smithsonian vol. 31, no. 12 (March 2001), 50-62. As part of the commemoration of the Submarine Centennial, the USN declassified portions of Batfish's report and gave her CO permission to discuss the patrol. The popular account Blind Man's Bluff describes a 1969 mission during which the SSN USS Lapon trailed a Yankee over a number of weeks. See Sontag and Drew, Blind Man's Bluff, 121-139. Recent British publications are beginning to discuss some RN Cold War submarine missions but these are unofficial accounts. See in particular, Stuart Prebble, Secrets of the Conqueror: The Untold Story of Britain's Most Famous Submarine (London, Faber and Faber, 2012). 
to the limits." ${ }^{38}$ OSPs also showcased the vast potential of the Sub/Air team, with Auroras demonstrating they could cue O-boats into killing distance of Soviet submarines. The partnership was a true force multiplier, and strengthened MARCOM's overall surveillance capability. As Keith Nesbit recalled, "Surveillance is about building pictures, and we got better at it." ${ }^{39}$ That raised Canada's credibility with its allies, particularly the US, and emphasised that when MARCOM declared a submarine operating area it had the means to monitor activity in that area-a capability that increased enormously when the O-boats finally received towed arrays in the late 1980s. In terms of sovereignty, the advantages accrued from that recognition were invaluable. Finally, the skills and experience gained through OSPs enabled the submarine community to transition easily to future operational roles.

\section{Operations in Support of Other Government Departments}

The Cold War focus on providing training services and carrying out operational missions in support of NATO, left little opportunity - nor, it can be said, enthusiasm - for Canadian submarines to conduct missions in support of other government departments (OGD). Priorities changed with the end of the Cold War and on a number of occasions in the 1990s MARCOM responded to requests from the Department of Fisheries and Oceans (DFO) and the Royal Canadian Mounted Police (RCMP) to provide submarine support to enforcement and sovereignty operations. The ability of Oberons to operate covertly added a valuable capability to the arsenal of the DFO and the RCMP, and the operations themselves, which required sustained, close-range surveillance of transgressors, proved of excellent value in keeping submariners' skills at a sharp edge.

Most important, senior naval officers thought that participation in national missions would confirm the value of submarines to the broader public. After the cancellation of the controversial nuclear submarine project in the late-1980s, the navy attempted to salvage the conventional submarine replacement program that had been torpedoed by the failed SSN procurement. However, there was general reluctance within government circles to discuss any submarine procurement program, and the navy sought ways to bring it back to the front burner. In October 1993, the head of operations on the MARCOM staff informed his Maritime Forces Atlantic (MARLANT) counterpart that senior naval officers "would like to raise the profile of our submarines in the public eye if possible to set the scene for future posturing on the submarine replacement issue":

To accomplish this they have suggested the following activities, some of which our submarines have been involved in the past:

A. Counter Drug Operations including exercises with the RCMP;

B. Fisheries patrols with DFO personnel embarked;

C. Embarkation of an RCMP SERT Tem and exercise boarding ships and/or scaling rigs;

D. Adriatic Deployment.

2. Request that the above noted employments be considered whenever possible for

38 Hickey to author, 24 December 2007.

39 Nesbit to author, 9 January 2008. 
our operational submarines. MARCOM will attempt to progress the Adriatic Deployment option. ${ }^{40}$

Despite considerable effort on behalf of MARCOM, an Oberon never made it to the Adriatic Sea as part of the Canadian naval contribution to NATO's Operation Sharp Guard. Nonetheless, it is no exaggeration that the successful support the O-boats provided OGDs in just a hand-full of missions garnered the Canadian submarine service more publicity than their operations during the entire Cold War.

Oberons, in particular HMCS Ojibwa, provided valuable surveillance support to the RCMP in a number of counter drug operations, and in at least one case their participation led directly to a successful prosecution after the submarine observed the exact position of a drug cache that was dumped overboard from a vessel smuggling drugs. However, the highest profile missions in support of OGDs were the fisheries patrols carried out by Ojibwa on the Georges Bank in March 1993 and by Okanagan off the Nose and Tail of the Grand Banks in the autumn of 1994. Beyond providing critical assistance that helped to strengthen Canada's position on international fisheries issues and increasing awareness of the capability of submarines, the success of these two missions enabled Canada to use the Oberons as a deterrent during the 1995 Turbot Dispute with Spain and the European Union, even though a boat never put to sea.

Sea-going poachers of any nationality are crafty adversaries and that trait was particularly evident on the Georges Bank south of Nova Scotia in the early 1990s. Historically, the Georges Bank had been a vibrant fishery consisting largely of ground fish and scallops ${ }^{41}$ but beginning in the 1960s fish stocks declined drastically when foreign (that is, non-North American) fishing fleets moved from the increasingly bare shelves of the Northwest Atlantic into the bountiful Gulf of Maine. The situation improved after Canada and the US established 200-mile exclusive fishing zones (EFZs) in 1977 but the two countries disputed ownership of Georges Bank. They submitted the case to the World Court which in 1984 established the Hague Line to delineate the maritime boundary. The decision, according to a US study, gave the best fishing grounds, the Northeast Peak, to Canada, and over the next few years scallop beds on the American side were decimated by liberal controls that saw some 300 US fishing vessels registered to fish the area. In contrast, scallop stocks remained strong on the Canadian side of the Hague Line where annual permits were given to just 35 boats. Not surprisingly, as a contemporary DFO study indicated, the Canadian side of the line became a lucrative area for Americans who had long considered it their own:

The scallop poacher penetrates into Canadian water under cover of night or fog. For the night or while the fog lasts his swath of dragging increases further and deeper with each new pass until he has taken all he can. He takes a more mature, larger and

$40 \quad$ N3 MARCOM to N3 MARLANT, 26 October 1993.

41 The term ground fish refers to cod, flounder, Pollack, haddock, monkfish and other finfish generally found near the ocean bottom, which are normally harvested by trawlers or draggers dragging nets. See James Wilson, "Maine's Fisheries," Blaine House Conference White paper, July 2007, 3 n2. Wilson is with the University of Maine's School of Marine Sciences. 
therefore more valuable Canadian scallop. Not only is he poaching; he is also over fishing the area....They take approximately 5,000 lbs of scallop every night they are on the Banks. They return to the US side of the Hague Line before sunrise to process the catch during the day. Then they repeat the procedure again the next evening and so on until they have a full processed load. In a few days they have a catch worth a hundred thousand dollars on the US market at New Bedford. ${ }^{42}$

In 1992 DFO detected four violations of U.S. fishing vessels poaching on the Canadian side of the Hague Line, but normal surveillance did not appear to be much of a deterrent, and if trends continued Canadian stocks would become as depleted as on the American side. In the late summer of 1992 the director of the enforcement branch, DFO suggested to Captain (N) J.A.Y. Plante, an experienced submariner, that an Oberon might prove valuable in enhancing the department's surveillance and enforcement capability. That initial discussion was followed up by a formal request, and after further discussions between DFO, MARCOM and MARLANT, Ojibwa was made available in March 1993. ${ }^{43}$

This was not the first time that MARCOM had utilized a submarine for a fisheries patrol, although the last occasion had been nearly two decades earlier. In March 1975 Okanagan deployed to the Nose and Tail of the Grand Banks with three destroyers and MPA support to test procedures for how mixed forces could detect and apprehend fisheries violators. The plan was for the submarine to conduct covert surveillance of fishing areas, and, if it detected illegal activity, to vector in the destroyers waiting over the horizon to arrest the violator. This novel concept was never tested as bad weather and poor sonar conditions on the Banks forced cancellation of the mission after four days. It appears the operation was never remounted. ${ }^{44}$

The 1975 deployment had been strictly a MARCOM operation, but DFO was fully involved in the planning for Operation Ambuscade, as the 1993 operation was dubbed., American enforcement agencies were also engaged, an indication of the high level of bi-lateral cooperation in enforcing the Hague Line. ${ }^{45}$ The Ambuscade operation order laid out three objectives:

42 J. Allan, "The Potential of a Submarine in Fishery Surveillance and Enforcement," 14 May 1993, p. 9. Allan, a former Commander MARCOM, was a partner in CFN Consultants and was contracted by DFO to write the report. It appears he was given access to DFO and DND records related to Operation Ambuscade.

43 Ibid, p. 10. It had initially been hoped to launch the operation in the autumn of 1992 but an Oberon was not available.

44 HMCS Okanagan Annual Historical Report [AHR] 1975. Interview with Ray Hunt, 16 August 2007. For a superb analysis of the navy's involvement in fishery patrols see Laurence M. Hickey, The Canadian Navy and Domestic Maritime Enforcement (Halifax: Dalhousie University, 2011).

45 Details of Operation Ambuscade are derived from the patrol report and supporting documents held by DHH, as well as Allan, "The Potential of a Submarine in Fishery Surveillance and Enforcement," and Maloney, "Canadian Subs Protect Fisheries." Lieutenant Commander R.E. Bush, then SUBOPAUTH at MARLANT recalls holding informal meetings to work out details of the operation with DFO representatives in the squadron wardroom. 
Primary. To detect, track, positively identify and initiate apprehension of fisheries violators; specifically, US scallop draggers operating in Canadian waters;

Secondary. To produce photographic, acoustic and electronic evidence in support of DFO and DND objectives; and

Tertiary. To conduct general surveillance of the assigned patrol area.

Ojibwa was to be the only warship involved, but was to be supported by CP-140 Aurora and CH-124 Sea King aircraft, as well as by DFO patrol vessels and aircraft, and US Coast Guard (USCG) patrol craft. DFO would be the lead agency for Ambuscade, and the DFO director general for the Scotia-Fundy Region would task DFO assets and liaise with DND and the USCG to support the operation. DND assets would remain under MARLANT command and control, and Commander R.E. Bush, the Submarine Operating Authority (SUBOPAUTH) at MARCOM, would control Ojibwa's activities, coordinate other DND support and serve as the point of contact for DFO. Most critically, a fisheries officer, Bernard Sullivan, was embarked in the submarine to provide technical information about fishing practices, and, if a violator was caught, to ensure that the appropriate evidence was gathered to support prosecution. ${ }^{46}$

To obtain such evidence, it was decided that Ojibwa had to detect intruders that had crossed in excess of one nautical mile across the Hague Line-DFO wanted proof of obvious intent - fix their position with sufficient accuracy to prove the incursion, identify the vessel, and sight their fishing gear at recovery or deployment. The boat's CO, Lieutenant Commander D. Marsaw, a skilled operational commander, was given several options to confirm the identity of contacts. He could track and observe covertly, and then call in DFO air and sea assets to track and board violators; he could track and observe, then pass the information to DFO to arrange interception by the USCG; or he could surface Ojibwa and illuminate and identify the violator, although it was recognized that the latter method held an element of risk for the submarine if the violator chose to react aggressively. No matter what option was utilized, Ojibwa had to maintain continuous contact with the violator.

Phase 1 of Ambuscade consisted of a training program on the Submarine Operations Team Trainer (SOTT) at the Fleet School. Formulated by Commander Bush, the training simulated a patrol on the Georges Bank and enabled Ojibwa's ops team to develop and practice various tactics. To provide technical expertise about fishing techniques, a DFO advisor participated in the two day serial. Besides sharpening skills and providing a comfort zone about what lay ahead, the training demonstrated that procedures not normally utilized on typical submarine operations would be essential to the success of this mission. Marsaw emphasized that the training scenarios "highlighted record keeping and evidence gathering requirements not previously considered, allowing those issues to be addressed prior to deploying."

Well-prepared and with clear cut objectives, Ojibwa departed Halifax on 5 March 1993, and upon arrival in the op area twenty hours later initiated Ambuscade. Contacting,

46 MARCOM HQ Halifax to NDHQ Ottawa, 272145Z February 1993. 
tracking and identifying fishing vessels presented different challenges than O-boats' usual activities against surface vessels, so Bush had inserted a shake down period to allow the ops team to adjust to the acoustic and environmental operating conditions. At $0010 \mathrm{Z} 7$ March, Ojibwa, proceeding submerged about six miles northeast of the Hague Line, detected a Canadian fishing vessel and Marsaw initiated tracking procedures to break the watch "gently" into working in close proximity to such targets with instructions not to approach any closer than 4000 yards during the night. To avoid counter-detection Ojibwa opened the range when snorting. At daylight Marsaw learned that "closing for identification was easy and I found that a range of 1000 yards was adequate for identification." One problem he discovered, however, "is that in the vicinity of fishing vessels, the high concentration of seagulls could be a counter-detection risk. The seagulls are attracted to the periscope and wheel about it vigorously." 47

Now relatively comfortable in the environment, Marsaw closed the Hague Line. At 1635Z Ojibwa detected an American dragger, which was designated contact "M02," fishing two miles inside the US side of the line. Marsaw moved to within 900 yards to ascertain its identity, and then withdrew to the line. Ojibwa kept at about 4000 yards, moving at about 4 knots at a depth of 52 feet. Plotting established that the vessel was trawling on an east-west line stopping just short of the Hague Line, but at 2330Z, in expectation of a transgression, Ojibwa's ops team "stood watch for apprehension of Fishing violator." 48 After night fell the dragger moved up to the line and at $0013 \mathrm{Z} 8$ March, the officer of the watch (OOW) noted in the patrol narrative that "M02 has altered course, believe he is closing the Canadian side. Good night clear, stars out, well lit by moon. Sea state is such as to cover periscope exposure while allowing good depth keeping. ${ }^{" 49}$ Minutes later the American vessel appeared to switch off its navigation lights and showed just a working light on its fantail. At 0028Z Ojibwa fixed it on the Canadian side of the line. Marsaw "took every SATNAV fix available and then took a visual bearing and radar range" to accurately plot his position. The vessel moved 1000 yards across the line and Ojibwa's sonar operators heard it winching in its gear, which was confirmed by periscope, providing clear evidence of a violation. "Unfortunately", Marsaw wrote in his report, "it appears that at that instant he was less than 1n[autical] $\mathrm{m}[\mathrm{ile}]$ inside the Canadian area." ${ }^{, 50}$ Throughout the rest of the night the fishing vessel was tracked manoeuvring on both sides of the Hague Line, and at daylight Ojibwa withdrew from the area.

Despite the instruction that violators had to be caught fishing at least one mile inside Canadian territory, it appears that the Fisheries Officer onboard Ojibwa had been tempted to apprehend M02. According to historian Sean Maloney's account of

$47 \quad$ Patrol Report, Annex J p. 1.

48 Patrol Report, Annex K, 7 March 1993. Canadian submarine patrol reports are a model of their kind, including great detail and numerous tactical appreciations by the Officer of the Watch and the Commanding Officer. The historian thus gets a clear understanding of what the submarine did and why it was done.

49 Patrol Report, Annex K, 8 March 1993.

50 Patrol Report Annex J, p. 2. 
Ambuscade, Sullivan thought in retrospect that he should have called in the DFO helicopter on station to make an arrest. ${ }^{51}$ As it turned out, it is fortunate he exercised caution since it soon became evident that Ojibwa's navigation had been flawed. Summarizing that night's watch in his officer of the watch (OOW) narrative, Lieutenant (N) M.E. Higginson observed:

Although it seemed M02 was violating the Hague Line, due to poor fixing and a significant tidal stream, OJIBWA was not where she thought she was. When a sat fix finally did come in, OJIBWA and [the fishing vessel] were both in American water. His navigation is apparently superior to our own. Judging by how often and how close he skirts the Hague Line I would say he knows exactly where he is. ${ }^{52}$

The American fishermen may well have been trawling across the line, but in a court of law Ojibwa's errors in navigation would have jeopardized prosecution, and probably resulted in embarrassment to Canada.

When addressing the navigation difficulties after the patrol Marsaw noted a number of problems. Experience after a couple of days on Georges Banks demonstrated the tidal set "often exceeded" that predicted in the tidal atlas available in the boat. The navigation aid Loran C "was virtually useless as even occasional mast washover caused chain slippage," a situation not helped by the fact that the Loran station on Cape Race was out of service. SATNAV was the "only navigation aid fitted that would have the continued accuracy needed...The great disadvantage of this method was that a convenient satellite was not always available and only through good luck would one be available coincident with the easternmost progress of the target." Something more than luck was obviously needed, and Marsaw concluded that "GPS [Global Positioning System] fitted to a workable mast would have been invaluable for an operation of this nature." ${ }^{53}$ At this time all units of the fleet were demanding GPS, but there were only a limited number of sets available, and submarines were low on the priority list.

After opening range to work on communications gear and dump "gash," Ojibwa returned to the Hague Line for the night of 8/9 March. This time Marsaw intended to take position inside the American side of the line and then head southeast parallel to the line gaining contact information. ${ }^{54}$ When Ojibwa encountered a US dragger at $1531 \mathrm{Z}$, Marsaw approached from the bow, which enabled the interception to be carried out at lower speed, reducing periscope vibration and making it easier to pick out the vessel's name and registration number. Marsaw later reported, "Of the three visual ID's I have done so far, this was the easiest." The vessel did not cross the line, and fighting problems with LORAN and the low light camera (LLTV), Marsaw pulled away. When those systems were repaired Ojibwa headed back towards the line only to have to again withdraw when radar became defective.

Over the next 48 hours Ojibwa tracked a number of contacts but continued to be

\footnotetext{
51 Maloney, "Canadian Subs Protect Fisheries," 75.

52 Patrol Report, App K, 11008 March 1993.

53 Patrol Report, Annexes A and D.

54 Patrol Report, Annexes J and K.
} 
frustrated by the navigation challenge and the behaviour of fishing vessels. To ensure accurate navigation watch-keepers took a LORAN fix every 15 minutes but Marsaw's confidence in the system was so low that he knew he would have to confirm any violation through SATNAV, "which makes it much more difficult and may prevent establishing his eastern most progress." Tracking was complicated by the high number of contacts, both Canadian and American, many of which moved erratically in close proximity to the Hague Line. Marsaw observed that "the fishing vessels here are much less predictable than those on the Clyde [where Canadian submarines worked-up in the UK] and the OOWs are unable to cope, therefore I am reluctant to get embroiled with them unless I am in the control room." Nonetheless, on 9/10 March Ojibwa intermittently tracked three American vessels including one Sullivan identified as a repeated violator. Ojibwa tracked it as it crossed the line but it only penetrated 500 yards on the Canadian side. An exasperated Marsaw noted "We have maintained track on him thus far and should he get brazen we will be able to initiate his arrest." $" 55$

With the patrol nearing its conclusion and an arrest proving elusive, plans were put in motion to at least fulfill the deterrence aspect of Ambuscade. On 10 March Marsaw recommended that if Ojibwa was "unable to firmly establish a violator's pos[itio]n in excess of 1NM inside CAN water PR opportunity should exist to surface near someone who is crowding the line." ${ }^{56}$ MARLANT disagreed. They were concerned that if the submarine surfaced in close proximity to a fishing boat, even if just for photographic purposes, the fishing vessel might be spooked enough to react aggressively and endanger the submarine. At $2111 \mathrm{Z} 10$ March, Commander Bush informed Marsaw that a group of Canadian fishing vessels were working in the area and "prefer that you use one of these vessels for overt PR photos rather than surprise someone." To that end MARLANT would warn them "they may get a visit from you," and CFB Shearwater was tasked to provide an aircraft and photographic team for the job. ${ }^{57}$

A photograph of Ojibwa surfacing alongside a Canadian fishing vessel would publicize that a submarine was monitoring fishing on the Georges Bank, but more dramatic action was needed to jar the Americans poaching across the Hague Line. After tracking two vessels for a number of hours, at 0405Z, 11 March Sullivan raised them on VHF from the submerged submarine. According to Marsaw's report, "Officer Sullivan contacted the captains of both vessels by radio and identified himself as a Fishery Officer on board the Canadian submarine Ojibwa. He advised the captains their vessels' movements had been tracked over the last few days and he advised the captains if they strayed across into Canadian waters again they would be charged." The emotionally charged response of the Americans is now legendary throughout MARCOM. Once they settled down, both captains acknowledged the message, and minutes later an Aurora punctuated the warning by overflying the two fishermen at low altitude. The warnings caused immediate alarm. In Halifax sailors monitoring the communications network overheard the Americans spreading the warning that a submarine was present, and one

55 Patrol Report Annex J. Ojibwa to MOC 100115Z 10 March 1993.

56 Ojibwa to CTG $302.90115 Z 10$ March 1993.

57 CTG 202.9 to Ojibwa 2111Z 10 March 1993. 
fisherman protested to Ojibwa that it was not just he crossing the line but others as well. ${ }^{58}$ Later, the New Bedford Standard Times newspaper contacted DFO, who gladly expanded upon Ojibwa's role. Canadian media also picked up the story. Ambuscade thus became common knowledge and for a time at least U.S. fishermen had to assume that a Canadian submarine might be covertly observing activities along the Hague Line.

Ambuscade proved that an Oberon could locate, track, identify and monitor the activity of scallop draggers, and do it covertly. Moreover, a submarine could obtain and record acoustic signatures of various fishing vessels and link them to a specific identity, confirmed visually by periscope. This helped to build a data base with the result that, as in the case with Soviet submarines, individual fishing vessels could be identified by their unique acoustic signatures. The operation also provided useful training and experience for ops teams, especially in building plots in a high traffic area, a rare opportunity in Canadian waters. Ambuscade had also provided useful lessons, especially the necessity of fixing the precise position of violators on an uninterrupted real time basis, and although Ojibwa's SATNAV and LORAN C systems proved unable to do that consistently, a solution was close on the horizon in GPS. In terms of deterrence, a submarine would have to be visible on the Georges Bank fairly consistently to persuade American poachers that a submarine might be present at any time. However, with just three boats, all in great demand for operations and training and having to meet maintenance requirements, that proved impossible to achieve. Nonetheless, there was a short term pay-off since violations of the Hague Line decreased from 33 in 1993 to just one in $1995 .^{59}$

The situation on the Grand Banks was considered far more serious than that on Georges Bank. ${ }^{60}$ The once bountiful cod fishery had collapsed, and in 1992 the Canadian government declared a moratorium on cod fishing. Canada laid the blame for overfishing on members of the European Union, particularly Portugal and Spain. ${ }^{61}$ The EU countered that Canada had mismanaged the cod fishery, but conceded stocks were in crisis and agreed to adhere to the moratorium on cod fish and certain other species of ground fish. EU nations increasingly turned to fishing Turbot, the North American name for the Greenland Halibut, and that stock was soon under pressure, to the point that a 1994 DFO study suggested that the stock had declined by two-thirds since the late 1980s. Given the level of crisis and the attention it was garnering, enforcement of fisheries regulations became a critical issue, and, based on the success of Ambuscade, in 1994 DFO asked if a submarine was available to carry out surveillance on the extremities of

58 Patrol Report, Annex K; Ojibwa to CTG 302.9 0439Z 11 March 1993. Bush to Author, 17 September 2007.

59 CDR L.M. Hickey, "The Submarine as a Tool of Maritime Enforcement," Integrated Coastal Zone Management (Spring 2010), 118.

60 Much as been written on the fisheries crisis on the Grand Banks in the early 1990s; this section is based primarily on Elizabeth Sneyd, "Fighting Over Fish: A Look at the 1995 Canada-Spain Turbot War," MA Dissertation, Royal Military College of Canada.

61 Portugal and Spain acceded to the EU in 1986 and the number of EU vessels on the Grand Banks jumped from 10 to 120 . 
the Grand Banks. As with Ambuscade, the concern was that EU and other fishermen were breaking the law when DFO assets were not in the area or at night or during poor visibility when their poaching could not be observed. The navy made a submarine available, and in September 1994 Okanagan was tasked for Operation Grouse, a fisheries patrol off the 200-mile limit of the Grand Banks. The boat's CO was Lieutenant Commander L.M. Hickey, who had commanded Onondaga on a particularly demanding OSP in November $1986 .{ }^{62}$ Comparing the two operations, Hickey later noted that Grouse was "a military surveillance operation whose targets of interest just happened to be fishing vessels."

Although the objectives of Grouse were virtually identical to those for Ambuscade, the mission on the Banks presented more of a challenge. ${ }^{64}$ Instead of patrolling the relatively short 60-mile section of the Hague Line that crossed Georges Bank, Okanagan's area of operations covered the Nose and Tail of the Bank, Flemish Cap as well as adjacent waters, an area of about 65,000 square miles. The area encompassed both shallow and deep water, each with its own distinct surveillance challenges. Also, rather than observing fishing vessels from just two nations, Okanagan had to detect and identify vessels from a number of countries, some of whom were not signatories to the Canadian moratorium and who could therefore not be apprehended. Complicating that was the fact there were typically more vessels fishing on the Grand Banks and they were scattered over a much larger area. Other complications added to the difficulty of the mission. The embarked DFO officer would not just provide advice as in Ambuscade, he would actually direct Okanagan's movements to the areas he thought would be the most fruitful for surveillance. In terms of assets besides the submarine, DFO would have patrol vessels in the area and provide periodic aerial surveillance, while MARLANT would provide CP-140 Aurora support. The destroyer escort HMCS Fraser would also be on the Banks as part of fisheries patrol FISHPAT 7/94 but beyond quickly discussing communications procedures just before the destroyer sailed, there was no real opportunity for her $\mathrm{CO}$ and Hickey to coordinate movements or procedures. ${ }^{65}$

Although DFO and MARLANT tried to work closely together in Grouse it became apparent to Hickey that they had different aims for the operation. "Okanagan's objective, as far as the Navy was concerned," he explained, "was to effect the arrest of a violator":

Of secondary importance was the gathering of intelligence on fishing vessels, and compiling a picture of their patterns of operating, with SIV's and HIV's ${ }^{66}$ being the priority targets. On the other hand, DFO was interested in determining whether or not

62 See Whitby, "'Doin' the Biz'."

63 See Hickey, "The Submarine as a Tool of Maritime Enforcement," 118.

64 Operation Grouse Patrol Report, 27 October 1994. Except for the TOI the patrol orders for Grouse and Ambuscade were identical.

65 Operation Grouse Patrol Report, Annex C. MARLANT HQ, "Patrol Orders - HMCS OKANAGAN", 16 September 1994. There is no reference to Fraser in Okanagan's patrol instructions. Unfortunately, Fraser did not submit an AHR for 1994. 
fishing vessels were using inclement weather and darkness to fish illegally, either on the Tail/Nose for protected species, or crossing into the 200-mile EEZ. DFO's interest was in the Spanish and Portuguese fishermen. Arrest of violators was of secondary importance. ${ }^{67}$

As Hickey recognized, the variance was the result of differing institutional philosophies:

Since enforcement is routine for DFO, they have a long-range perspective on the way they conduct business, ie. "if we don't catch them this time, we'll catch them later." On the other hand, naval units have a short-term desire for significant incident, eg. an arrest of a violator. The Navy's perspective tends to view the patrol as a two-week window during which something has to be achieved, something concrete that can be pointed to and the statement made, "Look what we did."68

As long as submarines remained scarce assets in high demand and support to DFO remained a secondary duty, this situation was bound to exist. Confronting it at sea in Okanagan, with the embarked DFO officer directing the operation, Hickey could only rely upon "flexibility and compromise" to make the most of the situation. ${ }^{69}$

Okanagan departed Halifax at 100026 September to commence her two-day passage to the extremity of the Grand Banks. As they headed east, Hickey and the DFO officer worked out their plans for the patrol and frustration soon arose over coordination and support. The DFO officer decided initially to head to the vicinity of the Tail of the Bank to verify that foreign fishing vessels were not using a gaggle of Canadian swordfishermen as cover to fish illegally. He then wanted to head eastward into deep water for four or five days to determine the movement patterns of foreign vessels heading northwards from the 800 meter line towards the 200-mile boundary. To gain an understanding of the surface picture, Hickey requested the positions of Canadian and foreign fishing vessels in the area, and asked for the schedule of DFO air patrols for the coming week. ${ }^{70}$ Hickey was initially told that King Air, the company contracted to carry out this surveillance, flew a daily patrol but that its flight plan was not determined until just before take-off to ensure optimal weather. Thus, when the flight program was sent to Okanagan, MARLANT warned that the schedule was subject to change at short notice. As if that was not enough, Hickey could not communicate directly with the aircraft because the "[frequencies] embarked DFO has on the back Fag [cigarette] packet don't appear to work."71 Aerial surveillance support was obviously going to be key to GROUSE, and although it did indeed prove useful when it was received, it arrived sporadically.

Coordination with surface units was no better. On the evening of 28 September while Okanagan shadowed a Portuguese fishing vessel from about 1000 yards astern on

67 LCDR L.M. Hickey, “Command Lessons Learned”, 27 October 1994, p 1.

68 Ibid.

69 Ibid.

70 Okanagan to MARLANT, 0630Z and 2342Z 27 September 1994.

71 Okanagan to MARLANT, 2315Z 28 September 1994. 
her starboard quarter, Hickey took a routine all around look with the periscope and was startled to see Fraser at 3000 yards passing down the port side of the fishing boat. The destroyer turned towards Okanagan nearly forcing her deep, and Hickey raised the communications mast "to let her know we're here, and try to determine her intentions." Fraser passed a surface sitrep to Okanagan, which revealed that both the destroyer and the DFO vessel L.J. Cowley had been patrolling the area, and had boarded six vessels over the previous two days. Realizing that this would breed caution among potential violators, the DFO officer decided to disengage and move elsewhere. ${ }^{72}$ Thus, distinctly ad hoc mission planning and coordination eroded valuable submarine patrol time.

Okanagan headed towards deep water on the eastern side of the Tail to intercept Spanish trawlers reportedly heading to that area from Flemish Cap. On 29 September Okanagan intercepted three trawlers that were fishing legally. Before the patrol Hickey had expressed his intention to take more risks when shadowing fishing vessels than he normally would against warships, and his handling of one Spanish contact demonstrated his comfort in doing so. After sighting a trawler by periscope at about 8,500 yards and plotting it by sonar and intermittent radar hits, Hickey approached the target from ahead, starboard side to. Acoustics provided plenty of information including pulses from its fish finder, clatter from the winch, and continuous cavitation. Hickey took Okanagan in close. He later signalled MARLANT that he made an "effing close pass. Not fessing up to actual CPA since squad[ron] boss may read. Will have fudged records by [return to] Halifax." "73 In fact, the patrol records remained "unfudged," and reveal that Okanagan moved to within 200 yards of the trawler. Sneaking quick peaks through the periscope Hickey was close enough to see the boat make sternway as it reeled in its net, and since he could clearly observe the crew concentrating on their work on the fantail he knew there was little risk of counter-detection. Having collected imagery, Okanagan withdrew to about 2000 yards but the DFO officer asked him to move in again to see if he could ascertain the species of fish being caught. Unfortunately, the Spaniards recovered their nets before the boat could get close enough. ${ }^{74}$

For the next three days, Okanagan remained in deep water on the eastern side of the Tail, patrolling north and south along the 800-metre contour. Four Spanish trawlers were shadowed for extensive periods, and the submarine also encountered the EU fisheries patrol vessel Kommander Amalie trailing one of the same vessels. Her presence, reinforced by "Fishery Patrol" emblazoned in huge script on her hull, accounts for the fact that the trawlers fished legally and worked no closer than one mile from the 200-mile limit. Given this situation, Hickey and the DFO officer decided to shift patrol areas to Flemish Cap, reportedly "alive" with fishing activity. However, because the DFO office in St. John's closed on the weekend, approval could not be requested until Monday 3

72 Okanagan to MARLANT, 2315Z 28 September 1994. Patrol Report, Annex A, p 1-2; Annex H, pp. 9-10. Referencing the "rust out" factor in the Fleet, Hickey coyly reported to MARLANT, "Have verified that Fraser is still afloat."

73 Okanagan to MARLANT, 0753Z 30 September 1994.

74 Patrol Report, Annex A, p. 2, Annex B, p. 3, Annex H, pp. 22-26. DFO, "Submarine Fisheries Patrol," p. 4. Both the Significant Events log (Annex B) and the OOW Narrative (Annex H) confirm the approach to within 200 yards; the DFO report says 220 yards. 
October, which meant that the earliest the boat could get to Flemish Cap would be Tuesday, four days hence. "In order to determine the feasibility of pursuing this option," Okanagan arranged a rendezvous with the DFO vessel L.J. Cowley on the Monday. Since it was risky for the submarine to raise her communications mast with fishing vessels in the vicinity, the DFO officer could use Cowley's INMARSAT without exposing Okanagan to detection. Unhappily when they two vessels met on 3 October, a six-foot swell prevented boat-work. Hickey was unimpressed, and complained "Looks like Flemish Cap is out of the picture." 75

Frustration also continued due to problems with the aerial surveillance provided by DFO. During the meeting with the Cowley Hickey learned that a King Air flight on Saturday 1 October had "located two Spaniards fishing [illegally] up on the Bank but did not pass posns to MARLANT," preventing the submarine from being cued to the location. Hickey noted that his fisheries officer is "getting as annoyed at DFO as I am." MARLANT also expressed exasperation. On Tuesday they informed Okanagan, "Still awaiting DFO flight info for this week. Expecting it yesterday." 76 At $1615 \mathrm{Z}$ on Tuesday 4 October MARLANT finally transmitted DFO's approval for Okanagan to head to Flemish Cap, but by then Hickey and the DFO officer had reconsidered. ${ }^{77}$ Hickey later explained that permission "regrettably too late to make the dash. Would only have about 8 hrs daylight onsta[tion]." Instead, he requested intelligence of fishing activity on The Nose of the Bank and later announced his intention to shift to that area.

In the midst of this inertia and indecision, Okanagan had patrolled shallow water on the Tail of the Bank. On the morning of 4 October they shadowed a Canadian scallop dragger for a couple of hours, getting as close as 150 yards, but the boat was in transit and gave no indication she was going to commence fishing. Hickey later reported "the beauty of working shallow water is that no one is supposed to be here. Hence any vessel found here is suspect." ${ }^{78}$ That description certainly applied to an American fishing vessel Okanagan encountered that evening. She was transiting across shallow water and as Hickey explained in his patrol narrative, "DFO has a feeling that he will start fishing soon. Intend to fall in astern and watch for this to happen. If he fishes for flounder, will call in COWLEY, although not breaking law per se, it is still a violation of moratorium. If he fishes scallops, we'll arrest him." The next few hours confirmed the unique capability of a submarine to observe fishing violations. Night had fallen and it would have been difficult for an aircraft or surface vessel to monitor the vessel, but Okanagan monitored her acoustically and visually as she proceeded northeast at about nine knots with no

75 Patrol Report, Appendix H, p. 122. Both sides pointed the finger for the failure to conduct the pax transfer. Hickey complained, "The mighty all-weather DFO Boarding party chickened out of the boat transfer", while the DFO report noted that "Sea state and problems raising the Fore Planes on the submarine prevented the transfer."

76 Okanagan to MARLANT, 1838Z 1 October and MARLANT to Okanagan 1615Z 4 October 1994.

77 MARLANT to Okanagan 1615Z 4 October 1994. MARLANT complained "Regret time late but link to DFO is not as timely as it could be." 
evidence of fishing activity. After about two hours, during which time contact was lost but re-established, lines were finally sighted extending astern from the fishing boat. Okanagan immediately passed the information and her position to the L.J. Cowley who boarded the vessel at first light. ${ }^{79}$

With the end of Grouse now in sight, as on Ambuscade, discussion centred on the possibility of obtaining a photograph of Okanagan surfaced alongside a fishing boat to punctuate the operation. The navy was willing to complete the mission covertly but DFO wanted to publicize the submarine's presence on the Grand Banks, and as the lead agency that view carried the day. MARLANT instructed Okanagan that the image would be taken by the King Air flight on the morning of 7 October, and that the order of priority of the subject to be photographed was, first, European; second, any other nationality; and, then, Canadian: "US vessels are only to be used as a last resort." With that in mind, Hickey bypassed an American swordfisherman on the morning of 6 October but encountered another vessel later in the day. Shadowing throughout the night he had to approach to within 350 yards in darkness to identify her. He planned to surface next to her in the morning but the trawler led Okanagan into a fog bank, which prevented the King Air aircraft from taking a photo so Hickey broke off and, based on weather report from the L.J. Cowley, decided "to race north to try and locate another Spaniard in good vis[ibility]." The move paid off and they found a vessel trawling on the very eastern edge of the Tail of the Bank. Approaching submerged to within 450 yards, Okanagan identified her as the Pescamaro Uno. Okanagan stayed with the vessel until King Air arrived, and then surfaced 900 yards on its starboard beam. ${ }^{80}$ Hickey informed Halifax that the Spanish were shocked when the submarine surfaced in close proximity:

Sealand VHF 16 verified that OOW of Pescamaro Uno has commendable fluency of expletives in both English and Spanish. Synopsis of TX [text] goes like this quote Submarine Submarine four letter expletive referring to carnal knowledge times 3 followed by incoherent babbling in Spanish unquote. ${ }^{81}$

In a brief patrol synopsis Hickey informed MARLANT that Okanagan "binted, fingerprinted and verified ID of sixteen vessels/ $10 \mathrm{Spanish} / 2 \mathrm{US} / 2 \mathrm{Cdn} / 1$ Portuguese/ 1 Isle of Man/ Detected one violator who was turned over to DFO surface patrol craft." 82 This was clearly a good result but more detailed post action analyses pointed to a number of areas where improvements could be made. Not surprisingly, Hickey had strong opinions about command and control deficiencies that arose during Grouse. He explained that the patrol "was a fluid response to current intelligence", but unfortunately that provided by DFO through MARLANT "proved to be stale and time late." Okanagan's surveillance capability was also constricted by the ad hoc nature of the mission planning.

79 Patrol Report, App H p 136-145. A post-op briefing note explained that the extension of the protection area for straddling stocks only applied to Flag of Convenience vessels. LCDR L.B. Mosher, "Briefing Note: Operation GROUSE," 17 October 1994.

80 Patrol Report Annex A, p. 3; Annex H, pp. 179-191. Okanagan to MARLANT 1538Z 7 October 1994.

81 Okanagan to MARLANT, 1845Z 7 October 1994.

82 Ibid. 
The embarked fisheries officer "was given free rein by DFO as he saw fit, and this took the form of requests to cover large distances at best speed." As a result, the submarine "spent a considerable number of hours snorting at 8 to 10 knots to reposition," which was obviously not the optimal surveillance posture. Hickey also complained about the lack of mission planning, which had resulted in surface assets and Okanagan working at crosspurposes. He recommended that on future patrols surface vessels should "bait the trap" by operating in deep water, while the submarine positioned itself at least twenty miles away in shallow water, so as to catch vessels trying to take advantage of the absence of the patrol ship. Finally, due to DFO's adherence to a five-day, 0800-1600 routine, "if a violation is detected outside normal working hours, apprehension would have to be delayed until DFO went back to work." Hickey recommended that on future operations the plan of the day should be agreed upon the previous day, enabling the submarine to reposition or shadow during the hours of darkness. ${ }^{83}$ Solutions to these and other issues would be easy to sort out, and to that end immediately after Grouse, MARLANT dispatched officers from the intelligence, operations and submarine staff to St. John's to compare analyses with their DFO counterparts. ${ }^{84}$

Okanagan gathered a wealth of technical and tactical information that could help similar missions in the future. Hickey explained that boats could snort within 600010,000 yards of a target without fear of detection, that most fishing vessels boats had Iband radars which enabled a submarine to get in close under the lobe, that they were slow enough to be shadowed submerged, and that trawlers steered steady courses and speeds while fishing, whereas scallop draggers moved unpredictably. He also gave the various ranges boats had to approach targets to gain information such as fishing gear or side numbers under day or night conditions. He recommended that when operating in very close proximity to a target at night that the search periscope be manned by an experienced officer while the $\mathrm{CO}$ used the attack scope. He also found that when trying to approach to within a CPA of 500 yards, closing from the quarter proved the safest, most controlled approach with little risk of visual counter-detection. Okanagan gathered an immense amount of material about fishing procedures, the particulars of individual vessels, crew positions, as well as acoustic and ELINT profiles, all of which was added to the fishing vessels' data base.

GROUSE proved to have one tangible success. After the settlement of the Turbot dispute that had erupted between Canada and Spain in the first months of 1995, a photograph of a Spanish fishing vessel taken through the lens of a submarine attack periscope from very close range appeared on the front page of the 8 June edition of the Toronto Sun. The accompanying headline blared, "Canada to Spain: We're Watching You...And This Is How We Do It." The message was simple: a Canadian submarine was at sea monitoring the activity of fishermen. In fact, no Canadian submarine had been on the Grand Banks during the "Turbot War" and the photo had actually been taken by Okanagan the previous year. Yet, during the dispute, MARCOM used a variety of

83 Patrol Report; App C, “Command Lessons Learned," pp. 1-2.

84 Capt (N) J.D. Fraser, "MARLANT/DFO Analysis of Op Grouse," 7 October 1994. Fraser was N3, ACOS P\&O. 
mechanisms to attempt to convince others they had actually deployed a submarine into the area ${ }^{85}$ It is not known if anyone was fooled by this ruse, and if so what impact it had; however, the Canadian public was evidently convinced that one of their submarines had been at sea defending our fisheries. That probably garnered the submarine service more positive publicity than it had ever received before.

Interestingly, the navy missed an opportunity to continue accruing such publicity. In November 1996, as the operational careers of the O-boats wound down, Okanagan carried out what amounted to a "drive-by fishpat" on the Grand Banks. Okanagan was on her way home from the UK, and MARLANT diverted her at short notice to conduct surveillance of fishermen thought to be harvesting shrimp illegally. Inclement weather grounded the intended MPA support for much of the two-day operation but Okanagan managed to develop a good tactical picture based on intelligence from MARLANT and monitored the activities of a number of vessels. It is unclear if any were doing so illegally. When the operation ended, Okanagan's CO, Lieutenant Commander S.A. Virgin, requested permission to surface alongside a shrimp boat for publicity and deterrence value but MARLANT turned him down, noting the intent was always for Okanagan to remain covert throughout the mission. This would seem to have been a mistake, since such publicity would have not only have satisfied the objective of increasing the profile of the submarine service but contributed to deterrence by confirming that Canadian boats were conducting fishpats on a continual basis.

O-Boats carried out no further dedicated fisheries patrols after Grouse; indeed, they conducted no more sustained operational programs of any kind. In 1997 the government had finally committed to acquiring four Type 2400 Upholder class boats from the $\mathrm{RN}$, and to prepare for their arrival MARCOM began to decommission the Oberons. Okanagan was scheduled to be the second last to go but even as her crew prepared for her final ceremonial sail past they were able to provide yet further evidence of the unique capabilities brought by submarines. Search teams had difficulty locating the black boxes from SwissAir Flight 111, after it plummeted tragically into the sea off Peggy's Cove on the evening of 2 September 1998. MARLANT sent Okanagan into the area and literally within minutes her sensors pin-pointed the precise location of the flight data recorder, which was soon recovered by divers. Although a sombre occasion, the mission, the last carried out by an Oberon, was a fitting way to leave the stage.

\section{The Lesson}

The operational record of Canada's submarines since they first embarked upon sustained operational programs in home waters in the mid-1980s was impressive. It may be seen as even more so when the full story can be told. This alone would seem to justify their role in the Canadian maritime security environment. Yet, numbers have consistently been a problem, and it has been exceedingly difficult to meet commitments with the relatively small submarine fleet at the navy's disposal. Under such circumstances it is often only possible to mount occasional "one off" missions - as was usually done in the

85 Interview with RADM R. Davidson, 21 October 2010. Davidson was MARLANT's SUBOPAUTH at the time of the Turbot Dispute. 
1960s and 70s. Even though those can be successful, their intermittent nature works against the accrual of expertise, confidence and skill that flows from continual experience where lessons can be learned and solutions implemented. If an important lesson emerges from this study - beyond the obvious importance of submarines - it is that the implementation of sustained operational programs is critical to the maintenance and maturation of capability. Those who had the vision and foresight to initiate the OSP program, from which flowed success in other operational scenarios, set the Canadian submarine service on an effective course, and it presents an example current and future submariners will do well to follow. 